\title{
ORGANIZATIONAL BEHAVIOR IN THE CENTRAL PUBLIC INSTITUTIONS
}

\author{
Evelyne Ingrid MITU, Elena Loredana COMĂNESCU \\ "Valahia" University, Târgovişte, Romania \\ evelynetudorache@yahoo.com, lory_ela@yahoo.com
}

\begin{abstract}
Redefining recruitment systems and evaluating civil servants to take into account a number of general macroeconomic issues. Professionalization of the public function in order to identify future practical solutions to recruitment and evaluation processes is necessary to make a decision on several fundamental aspects of the public service system. Analysis of the relationship between the available human resources and the probable evolution of the quantitative and qualitative analysis of the existing resources as well as the design of future resources.
\end{abstract}

Keywords: human, resource, management, evolution, administration

\section{Introduction}

Improved human resource management in central government requires achieving balance from labor resources existing at a time and labor requirements for implementation of the strategy to strengthen public administration 2014-2020.

Rational use of resources, knowledge of the current state of recruitment systems in terms of the rules in force.

Professionalisation of the civil service in order to identify practicable solutions in the future on recruitment and evaluation processes is necessary to have a decision on several fundamental aspects of the civil service system. Analysis of the relationship between human resources available and the desired analysis probable evolution (quantitative and qualitative) of existing resources, and to design future resources, it is intrinsically associated with the following:

a) Redefining civil service system and limits of public powers (including reconfiguring the relationship public - private and redefining the boundaries between them);

b) Projected outcomes and impact of external factors (demographic change, climate change, technological developments, public trust) on public administration and human resource needs within it.

\section{Organization of the human resources department of the central government}

According to the OECD study Public Administration after "new public management", central government staff includes staff working in the following areas:

- developing policies,

- implement public policies,

- regulation and control activities,

- support activities including: human resources management, communication management and information technology infrastructure, financial management, procurement, audit [1]. 
Organizing human resources department of the central government operating on public policy development and rulemaking and control is shown in "Organizing human resources department of the central government"

- Human Resource Management Directorate;

- Deputy Director;

- Service personal management;

- Office HR strategies and regulations;

- Human Relations Service and Training;

- Negotiation of labor contracts

- Department organization payroll

- Department management of assets and interests declarations.

For institutions subordinated to central government, operating on the implementation of public policies, organizational human resources department looks like.

"Organizing human resources department for institutions subordinated central government":

- Human Resource Management Directorate;

- Personal training service;

- Establishing service public debts and management functions.

There is a difference quite obvious from the structure of the human resources department of the central public administration and governmental structure of the human resources department of an institution subordinated to the central public administration (lack department on regulatory activities and control institutions subordinated).

The central government can provide teams of specialists in human resources to meet work function staff, and in the institutions subordinated to central government can't create a whole department profile because the structure created is not sufficient to able to meet all its specific activities.

Teams of specialists in human resources from the central government would have to solve a range of complex issues, such as:
- working conditions and protection of employees;

- performance appraisal;

- training and development;

- management careers; planning staffing needs;

- recruitment, selection and employment of personnel;

- stimulating and rewarding employees.

Normally, the whole issue of human resources management is the responsibility of policy makers managerial hierarchical structures of each central public institutions, but each institution subject makers Managers in higher structures exhibits the operational procedures specific to them so that regulatory functions and control must exist at each institution, because of the uniqueness / specificity of each institution. Ex. MARD and subordinate institution - APIA).

Organizing human resources department has two key objectives:

- management personnel to prevent dissatisfaction: administration; workforce recruitment; social relations; wages;

- human relations to produce satisfaction;

- internal communication; conditions of employment; working conditions; staff training; management careers.

Improve human resource management in central government requires achieving balance of labor resources existing at a time and labor requirements for implementation of the strategy to strengthen public administration 2014-2020 [4].

Implementation from 2014-2020 strategy for strengthening public administration is necessary rational use of resources, knowledge of the current state of recruitment systems and personnel evaluation in terms of the rules in force.

The analysis was done in several ways, namely by reference to correspondence with the "principles of European administrative space" reform programs of the Member States, the regulatory system in the civil service and implementation system 
in civil service rules. One of the issues examined was that relating to the existence of a state civil service (especially as it was one of the most important and most discussed elements of the EU in the area of administrative reforms in the pre) and the its evolution. Conclusion on this subject was that, at first sight, then accession countries showed a good alignment in this area at European principles as regards administration, 7 of the 8 countries having and maintaining current status of the function public. The existence of the rules on the matter was assessed as a positive side, the need for such state is underlined by the officials questioned in the foundation of the study.

However, it was found that post EU statutes have not been fully implemented, the quality of implementation in decline. The legal basis in the civil service was subject to multiple events legislative (amendments), legislative instability is present, as all countries have achieved a low score on "predictability of rules" for the coordination and management of the public, concluding therefore it is imperative that central institutions with a consolidated position with sufficient powers and control policies coordination civil. It was noted that there is no single European model for management of the public, also.

\section{Recruitment system in public administration}

Regarding recruitment system was noted as very important principle of open competition. Thus, binding and complete advertising of vacancies in the public service is seen as a key tool associated with the European principles of public administration. In this regard, since 2008 all the countries examined have covered the announcement of vacancies, given the importance of announcing jobs. Open competition is a basic tool complementary concept of merit recruitment and a tool that supports the principles of professionalism and effectiveness.
Presentation and analysis of the shortcomings of the system of recruitment and performance appraisal can be made from two perspectives, namely: presentation deficiencies in the regulatory framework and present deficiencies in application of the rules.

Among the weaknesses identified by the public authorities and institutions on the recruitment process can be found:

- Strict rules regarding advertising ways to organize and conduct competitions;

- The gap between the minimum age for participation in the positions recruitment competition organized for holding public execution and the necessary recruitment competition organized for public office management;

- Limits of old unfit for public office leadership. We consider age limit of two years in the public service, leading to incompetence in the decision making and a structure for coordination with civil servants experienced much beyond the age of a civil servant leadership;

- Insufficient regulation of the procedure for deferment/suspension of conducting recruitment competitions, leaving room for interpretation so that legislative act can create blockage in staffing;

- Lack of standardized bibliographies identical posts - (which may lead to discrepancies in the process the existence of such terminology inconsistencies and gaps in the definition of concepts and lack of evaluation of the quality of recruitment in the public services.

All conflicting rules generates a multitude of obstacles in applying the rules.

- For example, there is a uniform rule regarding document proving seniority, making it very difficult to calculate seniority and seniority implicit in the positions required for the performance of public functions.

- Another example is the resulting lack unitary character on seniority regulated professions laws of matter and / or regulated professions. 
- Also, there is clear and consistent rules regarding how the equivalence of work performed outside the geographical area of Romania, especially in states with which Romania has signed agreements in this field. Equivalence problems are both in terms of seniority, especially in terms of seniority in the positions.

Another controversial area is the necessary studies occupying a public office. The legislation concerning education and education also underwent a variety of changes after 1990 the system entered and changes in both conceptual and procedural.

- Since the status of civil servants was established a classification of public functions in relation to their employment required studies, recruitment was conducted by reference to these conditions.

- Also, another problem of enforcement in the field of education has direct consequences for the recruitment process. In practice, poor monitoring of the application of these rules resulted in the issuance of certificates successive periods much larger than the period of one year certificates that either de jure or de facto lacked validity.

- Interpretation of rules by using improper interpretation techniques and the use of different methods of interpretations about the same time (at different times) are two of the major causes of deficiencies in the application. Point in the interpretation and application of rules, difficulties have arisen regarding to: the method of calculation of deadlines associated with or resulting from the contest procedure; offense by authorities and public institutions the principles underlying the organization and career development of civil servants covered by the provisions of Article 4 of government Decision 611/2008 approving the rules on the organization and development of career civil servants, with subsequent amendments and of Article 57 pare. (3) of Law no.188 / 1999, as amended and supplemented, by establishing specific conditions restricting access to public service for every citizen who meets the legal requirements;

- failure to properly advertising vacancies;

- establishing job descriptions of conditions (particularly education) that are not confined to the requirements, the purpose for which it is established position. In Romania, after joining the European Union, similar to countries that joined in the last wave of accession of Romania, some existing rules have not been applied according to the purpose for which they were governed.

A good example is that relating to the recruitment and evaluation of senior civil servants, on procedural rules are laid down for entry into the category of senior civil servants, career management and mobility of senior public officials, as amended and supplemented [5]. Although the specific rules applicable were set on the entry in the category of senior civil servants, career management and mobility of senior civil servants, those rules were not always applied according to the purpose and form in which they were governed.

Therefore, the legislature's intention was to regulate the entry into the category of senior civil servants through a national competition, usually held annually vacancies government inspectors. After the entry into this category should mobility be made for certain purposes prescribed by law on other public office in the category of senior civil servants. In practice, most of the functions in the category of senior civil servants were employed temporarily, while the function of government inspector became function that was applied mobility of senior civil servants, without mobility to achieve their purpose for which it was regulated.

- Another shortcoming of enforcement lies in the correlation of special statutes/ provisions of other laws of the same level, with the general statute. In this context, the lack of coordination at national level and the existence of special regulations adopted without correlation with the general statute 
of civil and public servants can lead to distortions of the expected result of the recruitment process.

A number of difficulties have occurred in recruitment are generated by members of the examination/the appeal and the secretaries of these commissions.

It must not ignore vulnerabilities that may be associated with the recruitment process, results of how to fulfill duties by members of the examination/the appeal, by the Secretary, also.

In this context there is a risk of vicious consequences of recruitment on short, medium or long term. These deficiencies, although not resulting from the way they are regulated or how rules are interpreted, may affect recruitment by introducing the system of people who are not confined to recruitment in the public service principles.

To minimize some of these risks National Agency of Civil Servants created and made operational extraction system for the written electronic recruitment competitions to fill public positions in general management and specific [6,7,8]. It is clear that this type of system, while providing a high degree of objectivity and impartiality of procedures for competition and evaluation knowledge of applicants for competitions in civil service was not taken as an example of best practice by the authorities and institutions their role as organizers of recruitment competitions.

\section{Conclusions}

In the medium and long term, the redefinition of recruitment systems and evaluation of public officials to consider a number of issues macro general: a) Redefining civil service system and limits of public powers (including reconfiguring the relationship public private and redefining the boundaries between them);

b) Projected outcomes and impact of external factors (demographic change, climate change, technological developments, public trust) on public administration and human resource needs within it.

To the extent there is an option to create objects of "specialists" in the administration, not necessarily will work in positions of strategic management, but may be included in these posts as well as the "essential" maintenance of "generalists" who will do the work, administrative functions "auxiliary" is required to be considered the need for training of specialists to acquire general skills needed for public administration.

For all staff composed of civil servants from the government is required to acquire a set of skills applicable to directors general (whether by training in academia or through initial training at work) irrespective of the tasks performed in public office. Development of quality standards/ frameworks general skills and competencies to support public authorities in setting specific indicators representative is recommended as both the European Union and applied internally on the analysis of the civil service law.

Requires balancing the relationship between university training programs for the public and demand for skills and profiles of public administration, also.

\section{References}

[1] Studiul - OECD Public Administration after „new public management”, (2010: 25-27);

[2] www.anfp.gov.ro-Analiză privindconsolidarea rolului ANFP şi/sau înfiinţarea unei instituţii cu atribuţii în gestiunea personalului contractual din administraţia publică, (2016);

[3] www.madr.ro, Guvernul României/2018;Organizarea departamentului de resurse umane;

[4] Hotărârea Guvernului nr. 909/2014privind aprobarea Strategiei pentru consolidarea administraţiei publice 2014-2020; 
[5] www.anfp.gov.ro - Raport care cuprinde rezultatele unei analize asupra legislaţiei în materia funcţiei publice realizată de către ANFP în cursul anului 2013;

[6] Legea nr.188/1999 privind Statutul funcţionarilor publici, republicată, cu modificările şi completările ulterioare;

[7] Raport care cuprinde rezultatele unei analize asupra legislaţiei în material funcţiei publice realizată de ANFP în cursul anului 2013;

[8] Legea nr. 7/2004 privind Codul de conduită al funcţionarilor publici. 